\title{
Building Standard Levels to Assess the Level of Some Elements of Fitness Related to Health among Junior Footballers
}

\author{
Nedal Ahmad Alghafary ${ }^{{ }^{*}}$ \\ Azeez Ahmad Alrahamneh ${ }^{2}$ \\ Yaseen Ali Mahjoob Al Maharmeh³ \\ Subhi Ahmad Qablan ${ }^{4}$ \\ Ibrahim Mohammad Barjas Abu Jamous ${ }^{4}$ \\ ${ }^{1}$ Assistant Professor, \\ Teaching Curricula in Physical Education, \\ Al-Balqaa Applied University, \\ As-Salt, Jordan \\ ${ }^{2}$ Associate Professor, \\ Department of Educational Sciences, \\ Al-Balqaa Applied University, \\ As-Salt, Jordan \\ ${ }^{3}$ Assistant Professor, Department of Sports Sciences, \\ The World Islamic Sciences and Education University, \\ Amman, Jordan \\ ${ }^{4}$ Department of Basic Sciences, \\ Teaching Curricula in Physical Education, \\ Al-Balqa Applied University, Salt, Jordan \\ *Corresponding Author
}

DOI: https://doi.org/10.36941/jesr-2022-0050

\section{Abstract}

This study aimed to build standard levels to assess the level of some elements of physical fitness related to health among the juniors of Al-Faisali Football Club Academy, as well as to identify the differences in the tests due to the variable of height, weight and age. The researcher used a set of standardized tests that have a high degree of validity and reliability to measure the physical fitness elements of the subject of the study. The sample included (123) young players registered in the academy. The study reached to build standard levels for the juniors of the Al-Faisaly Football Club Academy, as well as the results of the study showed that there are differences between the averages of tests of explosive power, agility, transitional speed and grip strength of the right and left hand due to the variables of age, height and weight, while there were no differences in the 10oom running tests and the 3o-second stomach repeat test due to the study variables. The study recommends building standard levels to measure the elements of fitness for other games, specifically for juniors.

Keywords: physical fitness, standard levels, football, Physical health 


\section{Introduction}

Football is one of the most popular sports among citizens, as this sport is practiced by both sexes and of different ages (Pfirrmann et al., 2016). The sport of football has developed remarkably and very significantly at the global level, as this development touched the physical and tactical skill aspect of this sport through sports training science programs (Foss et al., 2018).

The process of developing sports comes through expanding the base of the game and paying attention to the youth sector or age groups, and that the development process must be through clear training programs based on scientific foundations based on the results of scientific studies (BidzanBluma et al., 2018), and since sports training is an educational process subject to scientific foundations and principles. It aims to prepare the individual to achieve the highest possible level of sport in a certain type of sporting activity (Seiler, 2010).

The process of selecting and preparing players is based on scientific, objective, and transparent bases to determine the level of physical fitness, skill and planning for the players (Rodríguez-Rosell et al., 2017), where this process must be subject to an evaluation that determines the level of the players, and that the evaluation process means issuing judgments on the value of things, people or topics. The concept also includes improvement, development and modification. Evaluation is considered similar to judging things to show strengths and weaknesses. Evaluation in physical education requires the use of clear scientific standards and foundations (DeCelles et al., 2016).

To identify the strengths and weaknesses, it is necessary to establish specific foundations and criteria governed by standard criteria that determine the level of the player in a correct manner (Seiler, 2010). The results of tests and standards in the field of physical education are employed to select novice players in sports activity (Hughes et al., 2020).

Stricker et al (2020) also add that the tests that are applied in the field of physical education use raw grades, and these grades have no meaning unless we refer to a standard that defines the meaning of these values or grades.

Therefore, tests and standards are the best way to carry out the evaluation and comparison between players and to achieve the principle of justice and equality between individuals, there must be standard levels to facilitate the process of judging the results and their interpretation (Dauenhauer et al., 2019).

The use of standard levels and standards in the field of physical education has become a necessity, as certain conditions and appropriate tests and standards are set in the field of sports, such as tests to measure the level of physical fitness or skill to identify the appropriate physical level for the type of this sport ( $\mathrm{Wu}$ et al., 2019).

As mentioned above, the interest of young people in playing football is very high, and the spread of many football schools in most countries of the world has increased interest in football and encouraged parents to engage their children in this sport. Specific criteria that help determine the level of the emerging player, and allow the sports coach to begin the process of planning a successful sports training process. Hence, the idea of setting standards for age groups for those wishing to play football was crystallized.

\subsection{Statement of the problem}

Football is the most popular and popular sport in the world, and it attracts the attention of large segments of the world and both sexes (Elzinga et al., 2019). This sport has developed greatly, achieving advanced levels has become a preoccupation for trainers and researchers to reach high levels.

Since the development process needs scientific studies in the field of physical education that work on the availability of clear criteria and bases for selecting athletes or players, these criteria come through tests and standards to determine the capabilities and level of the player and the extent of the development of the player's physical and skill performance. 
Since there are individual differences between the players and each kind of the sport has certain characteristics, requirements, a level of physical fitness and a special skill, and this was indicated by the study of Paul et al (2015), as it showed different standard levels, especially for the type of the practiced sport, and since football has special physical requirements and these physical characteristics give a clear indication of the athlete's health status, and since the environment and geographical location affect the nature of these requirements, in addition to the researchers' work at the university in teaching physical and health education, and their knowledge of many studies in this field of sports training science, it was found that there is specificity for the level of physical fitness for each community or study sample. It was necessary to identify the levels of physical fitness for the young players participating in the Al-Faisali Football Academy in the city of Salt and to determine the scientific criteria for the levels of physical fitness for these age stages through standardized tests and measurement to determine the level of physical fitness because the old standards are difficult to apply to current societies. This is due to the difference in physical abilities from one stage to another and from one society to another and the development of the science of sports training. This is what prompted the researcher to do this study to determine the standard levels for this age group and to identify their physical fitness levels to benefit from them as criteria in determining the levels of physical fitness for players wishing to Practice football.

In light of what was indicated by the results of studies and scientific research and the researcher's experience in this field, the researcher was motivated to conduct this study and based on the foregoing, the problem of the study was identified in determining standard levels of healthrelated physical fitness for football juniors registered at the Al-Faisali Club Academy.

\subsection{Study Objectives: The study aimed to achieve the following objectives:}

First: Building standards for some elements of physical fitness for junior footballers at Al-Faisaly Club Academy.

Second: Identifying the differences in the levels of physical fitness among junior footballers at Al-Faisali Club Academy due to the chronological age.

Third: Identifying the differences in the levels of physical fitness among junior footballers in AlFaisaly Club Academy due to weight.

Fourth: Identifying the differences in the levels of physical fitness among junior footballers in the Al-Faisaly Club Academy due to height.

1.3 Study questions: This study seeks to answer the following questions:

1. What are the standard levels of some elements of physical fitness related to health for football juniors at Al-Faisaly Club Academy?

2. Are there differences in the levels of physical fitness among junior footballers at Al-Faisali Club Academy due to the chronological age?

3. Are there differences in the levels of physical fitness among junior footballers at Al-Faisali Club Academy due to age and weight?

4. Are there differences in the levels of physical fitness among junior footballers at Al-Faisali Club Academy due to age and height?

\subsection{Significance of the study}

Through what the theoretical literature and previous studies of this subject acknowledge, the importance of the study lies in the fact that it:

1. The study provides a list of the standard levels of some elements of physical fitness related to health for young football players.

2. Providing coaches with strengths, weaknesses, and the physical and skill level of young 
football practitioners.

3. The need for the International Library for such a study, which studies the science of sports training.

1.5 The limits of the study:

- Time limits: This study was conducted during the period between (25/7/ 2021 and 1/8/2021).

- Human limits: the current study was limited to the players participating in the Al-Faisaly Football Club Academy.

\subsection{The study definitions}

Physical fitness: It is the ability to carry out the daily burdens with strength and awareness, without undue fatigue, with a sufficient and possible amount to enjoy leisure time, practice popular hobbies, and face the physical pressures that a person is exposed to (Chen et al., 2018).

Al-Faisaly Club Academy: It is a sports school that trains football for the "junior" age groups and provides the clubs with distinguished players.

Standard score: It is defined as the score of each individual based on the number of standard deviation units at the mean (Snedden et al., 2019).

\subsection{Standard levels:}

Percentile: A scale that ranges from zero to 99 percentile (Guillen et al., 2021).

Percentile rank: It refers to a position that represents a specific value within a group of values arranged according to its amount, by means of the percentage of values located at, below or above that value (Miller, 2021).

Test: It is a method that gives us estimates or scores as a result of applying methods that are described as accurate (Otani, 2017)

Measurement: The quantitative estimation of objects and levels according to a specific framework of scientifically listed measurements (Östlund, 2011)

\subsection{Previous studies}

The study of Abu Shehab (2002) aimed at building standard levels of fitness elements for goalkeepers for soccer in Jordanian schools. The researcher used the descriptive approach and the study sample was chosen randomly. The percentile standard and a battery of ten degrees were built, and the researcher recommended using the criteria that were built when selecting, testing and evaluating goalkeepers.

Al-Hadabi (2001) conducted a study aimed at building standard levels for some elements of physical fitness for students of Sultan Qaboos University and comparing the levels of physical fitness according to the four school years. The researcher used the descriptive approach to suit the nature of the study, as the study sample was chosen randomly. The third-year students excelled in all healthrelated fitness items tests compared to the four-year students. Standard scores were determined for the four school years and all health-related fitness items. The researcher recommended the adoption of health-related fitness criteria resulting from this study as a basis for evaluating fitness items.

Al-Awadi et al., (2017) conducted a study aimed at building and designing a test battery to measure the general handling of football players. The researcher used the descriptive approach on a sample that was chosen by the intentional method from the fourth year level and used the appropriate statistical methods, which were and were adopted as a test battery to measure the handling in the foot time.

Bishr (2012) conducted a study aimed at building a physical fitness test for the Palestinian army 
personnel and building standard levels for the extracted battery vocabulary. To accept the factor in the light of the Gilford test, the researcher reached to construct levels using the percentile degrees of the physical variables in the study sample for both categories. The researcher recommended the application of the final battery extracted to measure the physical aspect of the members of the Palestinian army.

While Bassem, (2008) conducted a study aimed at building a scale of legal knowledge in handball for students of the College of Physical Education, the researcher used the descriptive approach in a survey style for its suitability and the nature of the study. The study population was represented by fourth-year level students, and the researcher reached a measure of legal knowledge of handball for students of the Faculty of Physical Education. The researcher recommended the adoption of the scale prepared as a tool in the quarterly exams for students of the Faculty of Physical Education in handball law subjects.

The study of Abdul Muti (2009) aimed to build a scale of the attitudes towards swimming and its relationship to the physical and skill abilities of students applying to join the Department of Physical Education, Faculty of Education, Al-Azhar University. It has high validity and reliability to measure the trend towards swimming. The researcher recommended the necessity of applying the proposed scale to the same students in a sequential manner throughout the four studies to know the trends towards swimming.

The study of Al-Rahahla (2006) aimed to build standard levels of physical fitness elements for female students of the Faculty of Physical Education at the University of Jordan. The researcher used the descriptive method in the survey method for its relevance and the nature of the study. The researcher reached a scale for the standard levels of physical fitness elements for the students of the Faculty of Physical Education at the University of Jordan. The researcher recommended the necessity of using this scale to determine the level of physical fitness among female students of the Faculty of Physical Education at the University of Jordan.

\subsection{Commenting on previous studies:}

It was found through previous studies similar to the subject of the study that some of them dealt with the standard levels of male and female students, such as the Rahala study (2006) and the Al-Hadabi study (2001), while some studies dealt with the army and the armed forces, such as the study of Bishr (2012), and that most of these studies confirmed the need for the existence of levels Clear criteria for each field or age group due to its importance in determining the level of physical fitness or skill for individuals.

This study was distinguished from the rest of the studies in that it was conducted to determine the standard levels for the age groups of football players and on the sample and the study population is new, and within the researcher's knowledge, no scientific studies were conducted in the field of football on the current study community for a long time.

The researcher benefited from these studies in formulating the study problem, setting the objectives of the study, and choosing the appropriate methodology for the nature of the study. The researcher also benefited from the mechanism of discussing the results of the study.

\section{Methodology}

Study Design: The researcher used the descriptive method represented by the cross-sectional survey method due to its suitability to the study objectives.

The study population and sample: The study sample consisted of (123) registered players in AlFaisali Football Academy for juniors, who were chosen intentionally by $75 \%$ of the study population, and their ages ranged between (9-16) years. 
Table 1: Demographic characteristics of the study participants

\begin{tabular}{|c|c|c|c|}
\hline Variable & Category & $\mathrm{N}$ & $\%$ \\
\hline \multirow[t]{4}{*}{ Age } & 9 - 11 years & 46 & 37.4 \\
\hline & $12-14$ years & 41 & $33 \cdot 3$ \\
\hline & $15-17$ years & 36 & 29.3 \\
\hline & Total & 123 & 100.0 \\
\hline \multirow[t]{4}{*}{ Weight } & $50 \mathrm{~kg}$ or less & 59 & 48.0 \\
\hline & More than 50 to $60 \mathrm{kgs}$ & 18 & 14.6 \\
\hline & More than 6o to $70 \mathrm{kgs}$ & 46 & 37.4 \\
\hline & Total & 123 & 100.0 \\
\hline \multirow[t]{4}{*}{ Height } & Less than $150 \mathrm{~cm}$ & 53 & 43.1 \\
\hline & $150-160 \mathrm{~cm}$ & 27 & 22.0 \\
\hline & More than $160 \mathrm{~cm}$ & 43 & 35.0 \\
\hline & Total & 123 & 100.0 \\
\hline
\end{tabular}

The following table describes the study sample and the homogeneity and parity among the study sample members

Table 2: Means, standard deviations and coefficient of variation for age, weight and height variables of the study participants $(\mathrm{n}=123)$

\begin{tabular}{|l|l|c|c|c|}
\hline Variable & Measurement unit & Mean & Standard deviation & coefficient of variation \\
\hline Age & Year & 12.69 & 2.31 & 18.20 \\
\hline Weight & Kgs & 52.73 & 11.45 & 21.71 \\
\hline Height & cm & 150.14 & 14.36 & 9.56 \\
\hline
\end{tabular}

Table (2) shows the values of the means, standard deviations, and coefficient of variation for measurements of age, weight and height of the research sample members. By reviewing these values, it appears that the average age of the research sample members reached (12.69) years, while their average weight was $52.73 \mathrm{~kg}$. As for the height variable, the average height of the research sample individuals was $(150.14) \mathrm{cm}$. The last column in the table shows the values of an important statistical indicator, which is the coefficient of variation that reflects the convergence and homogeneity of the measurements of the research sample members in these variables. It is noted that the largest value of this indicator has reached $(21.71 \%)$, which is within the normal limits of the data, where it is assumed that the value of this indicator does not exceed $50 \%$, which represents the percentage of the standard deviation from the arithmetic mean

\subsection{Tests, devices and tools used in the study:}

\subsubsection{First: the tests used}

The researcher reviewed many scientific studies and relevant literature in the field of study, such as the study of Bishr (2012) and Rahahla (2006), where the researcher built tests that achieve the goal of conducting the study.

The tests used in the study

1. Sit-to-prone stomach exercise test (Sit Up): To measure the strength of the abdominal muscles.

2. The horizontal jump test from stability (to measure the explosive force of the legs $/ \mathrm{cm}$ ).

3. The zigzag running test between the cones to measure the component of agility. The laboratory runs at the maximum speed between the cones for a distance of 30 meters (to measure agility). 
4. The 5o-meter sprint test (to measure the transitional speed/second).

5. 10oom running test (to measure periodic respiratory endurance).

6. The torso flexion test from a long sitting position (to measure the component of flexibility/cm).

7. Grip strength test for the right and left hand (dynamometer $/ \mathrm{kg}$ ).

\subsubsection{Secondly: tools and equipment}

1. Forms for data registration.

2. Playgrounds and sports arenas.

3. Dynamometer: A device for measuring grip strength of the hand

4. Stopwatch

5. A wooden ruler to measure flexibility

6. Cones and poles to measure agility.

7. Tape measure.

8. Marking pens.

9. whistle

\subsection{The study procedure}

1. The tests were conducted during the period between $7 / 25 / 2021-1 / 8 / 2021$

2. The tests were conducted inside the stadiums of the city of Salt.

3. The conditions of the tests were standardized for all participants in the study sample.

4. The study sample players were given sufficient time to warm up and adequate explanation about the test, and to make two attempts in all the tests, and the best attempt was recorded, taking into account the return to the sports recovery when the attempt began.

\subsection{Validity and reliability indicators}

\subsubsection{Validity}

To ascertain the validity of the study tool for application to the sample of the study, junior footballers, the researcher presented it to many referees, experts and specialists in the field of sports training, health, measurement and evaluation, to take their opinions and directions and make appropriate adjustments to the content and content of the test to measure the test for what it was prepared for. The researcher has reached the final tests.

\subsubsection{Reliability}

Table 3: Test-retest reliability method scores $(\mathrm{n}=\mathbf{2 2})$

\begin{tabular}{|c|c|c|c|c|c|c|c|}
\hline \multirow[t]{2}{*}{ Test } & \multirow{2}{*}{$\begin{array}{l}\text { Measurement } \\
\text { unit }\end{array}$} & \multicolumn{2}{|c|}{ Test } & \multicolumn{2}{|c|}{ Re-test } & \multirow{2}{*}{$\begin{array}{l}\text { Correlation } \\
\text { coefficient }\end{array}$} & \multirow{2}{*}{ Sig } \\
\hline & & $\mathrm{M}$ & SD & $\mathrm{M}$ & SD & & \\
\hline Stomach repeat (3o sec) & Times & 20.32 & 2.73 & 20.50 & 2.77 & 0.896 & 0.000 \\
\hline Horizontal jump from stability & $\mathrm{M}$ & 1.67 & 0.31 & 1.69 & 0.33 & 0.941 & 0.000 \\
\hline zigzag jogging with ball $30 \mathrm{~m}$ & Sec & $7 \cdot 90$ & 1.66 & 8.23 & 1.48 & 0.838 & 0.000 \\
\hline Running (5om) & Sec & $13 \cdot 35$ & 1.98 & 13.68 & 1.68 & 0.822 & 0.000 \\
\hline Running (100om) & Min & $5 \cdot 54$ & 0.51 & 5.60 & 0.51 & 0.824 & 0.000 \\
\hline Flex the stump forward from long sitting & $\mathrm{Cm}$ & 10.64 & 2.57 & 11.02 & 2.88 & 0.882 & 0.000 \\
\hline Right-hand grip & $\mathrm{Kg}$ & 32.64 & 5.90 & 32.95 & 5.62 & 0.932 & 0.000 \\
\hline Left-hand grip & $\mathrm{Kg}$ & 23.82 & 4.36 & 24.41 & 5.00 & 0.873 & 0.000 \\
\hline
\end{tabular}


Table (3) shows the results of the reliability of physical fitness tests calculated by the test-retest method. When reviewing the stability values, it was found that the lowest correlation value shown by the results was (o.822) for the 50-meter sprint test, and since this is the lowest value, which at the same time is greater than 0.70 . As well as since the maximum value that the reliability reaches is the correct one, and when reviewing the values of the significance level accompanying the stability, it turns out that all of them were less than 0.05 , which supports the hypothesis of accepting the reliability between the two tests. Therefore, it is concluded that these tests are reliable through the results of this exploratory sample.

\section{Results}

\subsection{First Research question:}

What are the levels of some health-related physical fitness elements among junior footballers at AlFaisaly Club Academy?

Table 4: Basic descriptive statistical indicators for the tests of some elements of physical fitness related to health among junior footballers in Al-Faisali Club Academy $(n=123)$

\begin{tabular}{|l|l|c|c|c|c|c|c|}
\hline Teests & Measurement unit & Minimum & Max & M & SD & Skewness & Kurtosis \\
\hline Stomach repeat (30 sec) & Times & 16 & 28 & 21.79 & 2.58 & .174 & -.286 \\
\hline Horizontal jump from stability & M & 1.20 & 2.60 & 1.83 & 0.35 & .474 & -.559 \\
\hline zigzag jogging with ball 30m & Sec & 5.50 & 11.80 & 7.30 & 1.64 & .991 & .274 \\
\hline Running (50m) & Sec & 8.11 & 17.00 & 11.70 & 2.30 & .373 & -.929 \\
\hline Running (10oom) & Min & 4.60 & 6.80 & 5.42 & 0.54 & .632 & -.235 \\
\hline Flex the trunk forward from long sitting & Cm & 7.00 & 16.50 & 12.27 & 2.70 & -.094 & -1.334 \\
\hline Right-hand grip & Kg & 23.00 & 49.00 & 36.59 & 6.67 & -.430 & -.822 \\
\hline Left-hand grip & Kg & 18.00 & 40.00 & 28.29 & 5.76 & -.132 & -.641 \\
\hline
\end{tabular}

Table (4) shows the values of some descriptive statistical indicators for the tests of some elements of physical fitness related to health among junior footballers at Al-Faisali Club Academy. The last two columns in the table refer to two important indicators describing the distribution of the data of the variables of the tests and how close they are to the behavior of the normal (ideal) distribution of the data, which are the skewness and kurtosis indicators. By reviewing the values of the skewness coefficient, it is found that the largest value of skewness appeared in the zigzag jogging test with the ball $30 \mathrm{~m}$, as it reached (0.991), and since this value is the largest among the other skewness values and that the values of this indicator are derived from the raw data, it indicates a close distribution of the data of the tests of fitness elements The physical value was derived from the normal distribution because the largest value was confined between the two values $(-3$ to +3$)$ as well as for the second indicator, which is kurtosis. It is noted that the largest value of this indicator appeared in the test of bending the trunk forward from long sitting as well, and since the large value of this indicator did not exceed the reference values coefficient of kurtosis $(-3$ to +3$)$ Also, this indicator provides a description that is close to a normal distribution of the data of the tests of some health-related fitness elements among the juniors of Al-Faisaly Club Academy in football.

Table 5: Decimal percentile criteria for health-related fitness tests $(n=123)$

\begin{tabular}{|l|c|c|c|c|c|c|c|c|}
\hline \multirow{2}{*}{ Percentile } & \multicolumn{7}{|c|}{ Health-related fitness tests } \\
\cline { 2 - 9 } & $\begin{array}{c}\text { Stomach } \\
\text { repeat (30 } \\
\text { sec) }\end{array}$ & $\begin{array}{c}\text { Horizontal } \\
\text { jump from } \\
\text { stability }\end{array}$ & $\begin{array}{c}\text { zigzag } \\
\text { jogging with } \\
\text { ball 3om }\end{array}$ & $\begin{array}{c}\text { Running } \\
(50 \mathrm{~m})\end{array}$ & $\begin{array}{c}\text { Running } \\
(1000 \mathrm{~m})\end{array}$ & $\begin{array}{c}\text { Flex the trunk } \\
\text { forward from } \\
\text { long sitting }\end{array}$ & $\begin{array}{c}\text { Right- } \\
\text { hand } \\
\text { grip }\end{array}$ & $\begin{array}{c}\text { Left- } \\
\text { hand } \\
\text { grip }\end{array}$ \\
\hline 10 & 19 & 1.42 & 11.80 & 17.00 & 6.80 & 9.00 & 26.00 & 19.00 \\
\hline 20 & 20 & 1.46 & 9.50 & 15.00 & 6.16 & 9.50 & 29.80 & 22.80 \\
\hline
\end{tabular}




\begin{tabular}{|l|c|c|c|c|c|c|c|c|}
\hline \multirow{2}{*}{ Percentile } & \multicolumn{7}{|c|}{ Health-related fitness tests } \\
\cline { 2 - 10 } & $\begin{array}{c}\text { Stomach } \\
\text { repeat (30 } \\
\text { sec) }\end{array}$ & $\begin{array}{c}\text { Horizontal } \\
\text { jump from } \\
\text { stability }\end{array}$ & $\begin{array}{c}\text { zigzag } \\
\text { jogging with } \\
\text { ball 30m }\end{array}$ & $\begin{array}{c}\text { Running } \\
(50 \mathrm{~m})\end{array}$ & $\begin{array}{c}\text { Running } \\
(1000 \mathrm{n})\end{array}$ & $\begin{array}{c}\text { Flex the trunk } \\
\text { forward from } \\
\text { long sitting }\end{array}$ & $\begin{array}{c}\text { Right- } \\
\text { hand } \\
\text { grip }\end{array}$ & $\begin{array}{c}\text { Left- } \\
\text { hand } \\
\text { grip }\end{array}$ \\
\hline 30 & 20 & 1.56 & 8.60 & 14.00 & 5.80 & 10.50 & 32.20 & 25.00 \\
\hline 40 & 21 & 1.70 & 8.28 & 13.00 & 5.70 & 11.50 & 35.60 & 28.00 \\
\hline 50 & 22 & 1.80 & 7.20 & 12.20 & 5.50 & 12.00 & 39.00 & 29.00 \\
\hline 60 & 22 & 1.90 & 7.00 & 11.50 & 5.30 & 14.00 & 40.00 & 30.00 \\
\hline 70 & 23 & 2.00 & 6.30 & 10.60 & 5.20 & 14.50 & 41.00 & 31.00 \\
\hline 80 & 24 & 2.15 & 6.10 & 9.90 & 5.10 & 15.00 & 41.00 & 33.00 \\
\hline 90 & 25 & 2.40 & 5.88 & 9.50 & 4.98 & 15.50 & 44.00 & 35.60 \\
\hline 100 & 28 & 2.60 & 5.64 & 8.90 & 4.80 & 16.50 & 49.00 & 40.00 \\
\hline
\end{tabular}

Table (5) indicates the results of the decimal places for fitness tests related to health. By reviewing the results related to the stomach repeat test, it is clear that $(10 \%)$ of the research sample members have achieved (19) times or less, and that the best value in this test has reached (28) times, which was the maximum value.

As for the Horizontal jump from stability, the results showed that (10\%) of the research sample had achieved a jump distance of (1.42) meters or less, while the largest performance value for the research sample members reached (2.6o) meters, and the rest of the decimal percentile values ranged between these two values

In the zigzag running test with the ball for 30 seconds, it was noted that (10\%) of the students achieved the value (11.80), while the best category was among the research sample members in this test, which reached (5.64)

In the 50-meter running test, it was found that $(10 \%)$ of the research sample members achieved a value (17.00), while the maximum value achieved by the research sample members was (8.90) seconds.

In the 1000-meter running test, it was found that $(10 \%)$ of the research sample individuals achieved the value (6.80) minutes, while the value (4.80) minutes is the best result in performing this test.

As for the test of flexing the trunk forward from long sitting, the results showed that (10\%) of the research sample achieved the value (9.0o), while the maximum value in this test was the value $(16.50) \mathrm{cm}$.

In the right-hand grip strength test, it was found that $(10 \%)$ of the research sample achieved the value (26.0) and that the value of the greatest force exerted by some of the research sample members was (49.0) kg.

In the left-hand strength test, it was found that $(10 \%)$ of the research sample individuals achieved the value (19.0) and that the value of the greatest force exerted by some members of the research sample amounted to (40.0) $\mathrm{kg}$.

\subsection{The second question}

Are there differences in the levels of fitness related to health among junior footballers in Al-Faisali Club Academy due to chronological age?

Table 6: Means and standard deviations of physical fitness tests for junior footballers at Al-Faisaly Club Academy, distributed by chronological age $(n=123)$

\begin{tabular}{|l|c|c|c|c|}
\hline Tests & Age category & $\mathrm{N}$ & $\mathrm{M}$ & $\mathrm{SD}$ \\
\hline \multirow{3}{*}{ Stomach repeat (30 sec) } & $9-11$ years & 46 & 22.13 & 2.54 \\
\cline { 2 - 5 } & $12-14$ years & 41 & 20.76 & 2.61 \\
\cline { 2 - 5 } & $15-17$ years & 36 & 22.53 & 2.29 \\
\hline \multirow{3}{*}{ Horizontal jump from stability } & $9-11$ years & 46 & 1.52 & 0.14 \\
\cline { 2 - 5 } & $12-14$ years & 41 & 1.92 & 0.32 \\
\cline { 2 - 5 } & $15-17$ years & 36 & 2.11 & 0.24 \\
\hline
\end{tabular}




\begin{tabular}{|c|c|c|c|c|}
\hline Tests & Age category & $\mathrm{N}$ & M & SD \\
\hline \multirow{3}{*}{ zigzag jogging with ball zom } & $9-11$ years & 46 & 8.92 & 1.35 \\
\hline & $12-14$ years & 41 & 6.66 & 1.01 \\
\hline & $15-17$ years & 36 & 5.97 & 0.33 \\
\hline \multirow{3}{*}{ Running (5om) } & $9-11$ years & 46 & 13.19 & 1.57 \\
\hline & $12-14$ years & 41 & 11.80 & 2.51 \\
\hline & $15-17$ years & 36 & 9.67 & 1.00 \\
\hline \multirow{3}{*}{ Running (100om) } & $9-11$ years & 46 & $5 \cdot 50$ & 0.57 \\
\hline & $12-14$ years & 41 & 5.46 & 0.56 \\
\hline & $15-17$ years & 36 & 5.28 & 0.45 \\
\hline \multirow{3}{*}{ Flex the trunk forward from long sitting } & $9-11$ years & 46 & 10.32 & 1.55 \\
\hline & $12-14$ years & 41 & 12.27 & 2.84 \\
\hline & $15-17$ years & 36 & 14.76 & 1.34 \\
\hline \multirow{3}{*}{ Right-hand grip } & $9-11$ years & 46 & 31.43 & 6.08 \\
\hline & $12-14$ years & 41 & 38.17 & 5.63 \\
\hline & $15-17$ years & 36 & 41.39 & 3.11 \\
\hline \multirow{3}{*}{ Left-hand grip } & $9-11$ years & 46 & 24.28 & 5.60 \\
\hline & $12-14$ years & 41 & 28.98 & 4.14 \\
\hline & $15-17$ years & 36 & 32.64 & 3.81 \\
\hline
\end{tabular}

Table (6) reflects the values of the means and standard deviations of the physical fitness tests for junior footballers at Al-Faisali Club Academy, distributed according to chronological age. These mean scores are meaningful or statistically significant at the level of significance $(\alpha \leq 0.05)$. One way ANOVA analysis was used as shown in table (7).

Table 7: One-way analysis of variance (ANOVA) of physical fitness tests for junior footballers at AlFaisali Club Academy, distributed by chronological age $(n=123)$

\begin{tabular}{|c|c|c|c|c|c|c|}
\hline Tests & Source of variation & Sum of squares & Df & Sum of squares & $\mathrm{F}$ & Sig \\
\hline \multirow[t]{3}{*}{ Stomach repeat (30 sec) } & Between groups & 68.753 & 2 & 34.377 & \multirow{3}{*}{5.532} & \multirow{3}{*}{.005} \\
\hline & Within groups & $745 \cdot 751$ & 120 & 6.215 & & \\
\hline & Total & 814.504 & 122 & & & \\
\hline \multirow[t]{3}{*}{ Horizontal jump from stability } & Between groups & 7.716 & 2 & 3.858 & \multirow{3}{*}{65.731} & \multirow{3}{*}{.000} \\
\hline & Within groups & 7.043 & 120 & .059 & & \\
\hline & Total & 14.760 & 122 & & & \\
\hline \multirow[t]{3}{*}{ zigzag jogging with ball $30 \mathrm{~m}$} & Between groups & 201.174 & 2 & 100.587 & \multirow{3}{*}{95.124} & \multirow{3}{*}{.000} \\
\hline & Within groups & 126.892 & 120 & 1.057 & & \\
\hline & Total & 328.066 & 122 & & & \\
\hline \multirow[t]{3}{*}{ Running (5om) } & Between groups & 250.024 & 2 & 125.012 & \multirow{3}{*}{$37 \cdot 778$} & \multirow{3}{*}{.000} \\
\hline & Within groups & 397.098 & 120 & 3.309 & & \\
\hline & Total & 647.122 & 122 & & & \\
\hline \multirow[t]{3}{*}{ Running (100om) } & Between groups & 1.123 & 2 & .562 & \multirow{3}{*}{1.976} & \multirow{3}{*}{.143} \\
\hline & Within groups & 34.096 & 120 & .284 & & \\
\hline & Total & 35.219 & 122 & & & \\
\hline \multirow[t]{3}{*}{ Flex the trunk forward from long sitting } & Between groups & 398.894 & 2 & 199.447 & \multirow{3}{*}{48.551} & \multirow{3}{*}{.000} \\
\hline & Within groups & 492.964 & 120 & 4.108 & & \\
\hline & Total & 891.859 & 122 & & & \\
\hline \multirow[t]{3}{*}{ Right-hand grip } & Between groups & 2154.010 & 2 & 1077.005 & \multirow{3}{*}{$39 \cdot 551$} & \multirow{3}{*}{.000} \\
\hline & Within groups & 3267.665 & 120 & 27.231 & & \\
\hline & Total & 5421.675 & 122 & & & \\
\hline \multirow[t]{3}{*}{ Left-hand grip } & Between groups & 1438.856 & 2 & 719.428 & \multirow{3}{*}{33.120} & \multirow{3}{*}{.000} \\
\hline & Within groups & 2606.607 & 120 & 21.722 & & \\
\hline & Total & 4045.463 & 122 & & & \\
\hline
\end{tabular}


Table (7) shows a one-way analysis of the variance of physical fitness tests for junior footballers at AlFaisali Club Academy, distributed by chronological age, and by reviewing the significance level values shown in the last column of the table and comparing these values with the value (0.05), it turns out that there is one test, which is running 1000 meters The value of its significance level (o.143) is greater than 0.05 , which means that the averages of this test do not differ according to the chronological age of football juniors at Al-Faisali Club Academy

As for the rest of the significance level values, they were less than 0.05 , which indicates and suggests differences between the averages of the other seven tests according to the categories of the chronological age variable. To determine the age groups whose averages differ in each of the seven tests (other than the 10oo-meter running test), the least significant difference (LSD) test was used. The following table shows the results of this test Table (8) the results of the least significant difference (LSD) test to determine the age groups whose averages differ in physical fitness tests (statistically significant) for junior footballers at Al-Faisali Club Academy $(\mathrm{n}=123)$ (Table 8)

Table 8: Least Significant Difference (LSD) posthoc analysis of physical fitness tests for junior footballers at Al-Faisali Club Academy, distributed by chronological age $(\mathrm{n}=123)$

\begin{tabular}{|c|c|c|c|c|}
\hline Tests & Mean & Age category & $12-14$ years & $15^{-17}$ years \\
\hline \multirow{3}{*}{ Stomach repeat (30 sec } & 22.13 & $9-11$ years & * & \\
\hline & 20.76 & $12-14$ years & & \\
\hline & 22.53 & $15-17$ years & * & \\
\hline \multirow{3}{*}{ Horizontal jump from stability } & 1.52 & $9-11$ years & * & * \\
\hline & 1.92 & $12-14$ years & & * \\
\hline & 2.11 & $15-17$ years & & \\
\hline \multirow{3}{*}{ zigzag jogging with ball $30 \mathrm{~m}$} & 8.92 & $9-11$ years & * & * \\
\hline & 6.66 & $12-14$ years & & * \\
\hline & 5.97 & $15-17$ years & & \\
\hline \multirow{3}{*}{ Running (5om) } & 13.19 & $9-11$ years & * & * \\
\hline & 11.80 & $12-14$ years & & * \\
\hline & 9.67 & $15-17$ years & & \\
\hline \multirow{3}{*}{ Flex the trunk forward from long sitting } & 10.32 & $9-11$ years & * & * \\
\hline & 12.27 & $12-14$ years & & * \\
\hline & 14.76 & $15-17$ years & & \\
\hline \multirow{3}{*}{ Right-hand grip } & 31.43 & $9-11$ years & * & * \\
\hline & 38.17 & $12-14$ years & & * \\
\hline & 41.39 & $15-17$ years & & \\
\hline \multirow{3}{*}{ Left-hand grip } & 24.28 & $9-11$ years & * & * \\
\hline & 28.98 & $12-14$ years & & * \\
\hline & 32.64 & $15-17$ years & & \\
\hline
\end{tabular}

${ }^{*}$ It indicates that the means of the two groups differ statistically significant at the 0.05 significance level

By reviewing the results of the mean differences in the table, it is found that they were as follows:

In the 30-second stomach repetition test, the differences were between the juniors of the age group (12-14) years and the other two groups, so the significance was in favor of the other two age groups because their mean values were greater compared to the average age group (12-14) years, as shown in Table (8).

As for the rest of the tests in the table, the differences were between each two age groups so that the significance is in favor of the age group whose mean score is the largest in the jump test from stability, the forward flex the trunk forward from long sitting, and the right and left grip strength test, while the significance is in favor of the lower mean scores between the two groups comparisons in the $30 \mathrm{~m}$ and $50 \mathrm{~m}$ sprint tests 


\subsection{Third research questions}

Are there differences in the fitness levels related to health among junior footballers in Al-Faisaly Club Academy due to weight?

Table 9: Means and standard deviations of physical fitness tests for junior footballers at Al-Faisaly Club Academy, distributed by weight $(\mathrm{n}=123)$

\begin{tabular}{|c|c|c|c|c|}
\hline Tests & Weight category & $\mathrm{N}$ & $\mathrm{M}$ & SD \\
\hline \multirow{3}{*}{ Stomach repeat (30 sec) } & $50 \mathrm{~kg}$ or less & 59 & 21.54 & 2.53 \\
\hline & More than 50 to $60 \mathrm{kgs}$ & 18 & 21.78 & 2.26 \\
\hline & More than 60 to $70 \mathrm{kgs}$ & 46 & 22.11 & 2.77 \\
\hline \multirow{3}{*}{ Horizontal jump from stability } & $50 \mathrm{~kg}$ or less & 59 & 1.53 & 0.15 \\
\hline & More than 50 to $60 \mathrm{kgs}$ & 18 & 2.25 & 0.17 \\
\hline & More than 60 to $70 \mathrm{kgs}$ & 46 & 2.03 & 0.25 \\
\hline \multirow{3}{*}{ zigzag jogging with ball $30 \mathrm{~m}$} & $50 \mathrm{~kg}$ or less & 59 & 8.68 & 1.34 \\
\hline & More than 50 to $60 \mathrm{kgs}$ & 18 & 6.32 & 0.51 \\
\hline & More than 60 to $70 \mathrm{kgs}$ & 46 & 5.93 & 0.32 \\
\hline \multirow{3}{*}{ Running (5om) } & $50 \mathrm{~kg}$ or less & 59 & 13.58 & 1.59 \\
\hline & More than 50 to $60 \mathrm{kgs}$ & 18 & 11.54 & 1.14 \\
\hline & More than 60 to $70 \mathrm{kgs}$ & 46 & 9.35 & 0.60 \\
\hline \multirow{3}{*}{ Running (100om) } & $50 \mathrm{~kg}$ or less & 59 & 5.43 & 0.53 \\
\hline & More than 50 to $60 \mathrm{kgs}$ & 18 & 5.51 & 0.74 \\
\hline & More than 60 to $70 \mathrm{kgs}$ & 46 & 5.37 & 0.46 \\
\hline \multirow{3}{*}{ Flex the trunk forward from long sitting } & $50 \mathrm{~kg}$ or less & 59 & 10.15 & 1.48 \\
\hline & More than 50 to $60 \mathrm{kgs}$ & 18 & 12.89 & 2.93 \\
\hline & More than 60 to $70 \mathrm{kgs}$ & 46 & 14.75 & 1.19 \\
\hline \multirow{3}{*}{ Right-hand grip } & $50 \mathrm{~kg}$ or less & 59 & 31.58 & 5.65 \\
\hline & More than 50 to $60 \mathrm{kgs}$ & 18 & 39.33 & 3.60 \\
\hline & More than 60 to $70 \mathrm{kgs}$ & 46 & 41.96 & 3.00 \\
\hline \multirow{3}{*}{ Left-hand grip } & $50 \mathrm{~kg}$ or less & 59 & 24.54 & 5.18 \\
\hline & More than 50 to $60 \mathrm{kgs}$ & 18 & 30.00 & 3.94 \\
\hline & More than 60 to $70 \mathrm{kgs}$ & 46 & 32.43 & 3.50 \\
\hline
\end{tabular}

Table (9) shows the values of the mean scores and standard deviations of the physical fitness tests for junior footballers at Al-Faisali Club Academy, distributed by weight category. The differences in the values of these averages are meaningful or statistically significant at the significance level $(\alpha \leq 0.05)$. One way ANOVA was used, and Table (10) shows that:

Table 1o: One-way analysis of variance (ANOVA) of physical fitness tests for junior footballers at AlFaisali Club Academy, distributed by weight $(\mathrm{n}=123)$

\begin{tabular}{|c|c|c|c|c|c|c|}
\hline Tests & Source of variation & Sum of squares & Df & Sum of squares & $\mathrm{F}$ & Sig \\
\hline \multirow{3}{*}{ Stomach repeat (3o sec) } & Between groups & 8.292 & 2 & 4.146 & \multirow[t]{3}{*}{.617} & \multirow[t]{3}{*}{.541} \\
\hline & Within groups & 806.212 & 120 & 6.718 & & \\
\hline & Total & 814.504 & 122 & & & \\
\hline \multirow{3}{*}{ Horizontal jump from stability } & Between groups & 10.276 & 2 & 5.138 & \multirow[t]{3}{*}{$137 \cdot 505$} & \multirow[t]{3}{*}{.000} \\
\hline & Within groups & 4.484 & 120 & .037 & & \\
\hline & Total & 14.760 & 122 & & & \\
\hline \multirow{3}{*}{ zigzag jogging with ball $30 \mathrm{~m}$} & Between groups & 215.412 & 2 & 107.706 & \multirow[t]{3}{*}{114.730} & \multirow[t]{3}{*}{.000} \\
\hline & Within groups & 112.654 & 120 & .939 & & \\
\hline & Total & 328.066 & 122 & & & \\
\hline \multirow{3}{*}{ Running (5om) } & Between groups & 462.455 & 2 & 231.228 & \multirow[t]{3}{*}{150.256} & \multirow[t]{3}{*}{.000} \\
\hline & Within groups & 184.667 & 120 & 1.539 & & \\
\hline & Total & 647.122 & 122 & & & \\
\hline
\end{tabular}




\begin{tabular}{|c|c|c|c|c|c|c|}
\hline Tests & Source of variation & Sum of squares & Df & Sum of squares & $\mathrm{F}$ & Sig \\
\hline \multirow{3}{*}{ Running (10oom) } & Between groups & .289 & 2 & .144 & \multirow[t]{3}{*}{.496} & \multirow[t]{3}{*}{.610} \\
\hline & Within groups & 34.930 & 120 & .291 & & \\
\hline & Total & 35.219 & 122 & & & \\
\hline \multirow{3}{*}{ Flex the trunk forward from long sitting } & Between groups & 555.619 & 2 & 277.809 & \multirow[t]{3}{*}{99.147} & \multirow[t]{3}{*}{.000} \\
\hline & Within groups & 336.240 & 120 & 2.802 & & \\
\hline & Total & 891.859 & 122 & & & \\
\hline \multirow{3}{*}{ Right-hand grip } & Between groups & $2943 \cdot 355$ & 2 & 1471.677 & \multirow[t]{3}{*}{71.258} & \multirow[t]{3}{*}{.000} \\
\hline & Within groups & 2478.320 & 120 & 20.653 & & \\
\hline & Total & 5421.675 & 122 & & & \\
\hline \multirow{3}{*}{ Left-hand grip } & Between groups & 1671.515 & 2 & 835.757 & \multirow[t]{3}{*}{42.246} & \multirow[t]{3}{*}{.000} \\
\hline & Within groups & 2373.948 & 120 & 19.783 & & \\
\hline & Total & 4045.463 & 122 & & & \\
\hline
\end{tabular}

Table (10) shows a one-way analysis of variance for the physical fitness tests of football juniors at AlFaisali Club Academy, distributed according to the weight variable, and by reviewing the values of the significance level shown in the last column of the table and comparing these values with the value (0.05), it turns out that there are two tests, namely, the repetition of the stomach 30 seconds And the 10oo-meter running test, the value of the significance level of each of them, respectively (0.541) and (o.610), is greater than 0.05 , which means that the averages of these two tests do not differ according to the weight category of football juniors at Al-Faisali Club Academy. As for the rest of the significance level values, they were less than 0.05 , which indicates and suggests differences between the averages of the other six tests according to the weight variable categories

To determine the weight categories whose averages differ in each of the six tests (other than the 30-second stomach repetition test and the 1000-meter run test), the least significant difference test (LSD) was used. The results presented in table (11) shows the least significant difference test (LSD) to determine the weight categories whose averages differ in physical fitness tests (statistically significant) for junior footballers at Al-Faisali Club Academy $(\mathrm{n}=123)$

Table 11: Least Significant Difference (LSD) posthoc analysis of physical fitness tests for junior footballers at Al-Faisali Club Academy, distributed by chronological age $(\mathrm{n}=123)$

\begin{tabular}{|c|c|c|c|c|}
\hline Tests & M & $\begin{array}{l}\text { Weight } \\
\text { category }\end{array}$ & $\begin{array}{c}\text { More than } \\
50 \text { to } 60 \mathrm{kgs}\end{array}$ & $\begin{array}{l}\text { More than } \\
60 \text { to } 70 \mathrm{kgs}\end{array}$ \\
\hline \multirow{3}{*}{ Horizontal jump from stability } & 1.53 & $50 \mathrm{~kg}$ or less & * & * \\
\hline & 2.25 & More than 50 to $60 \mathrm{kgs}$ & & * \\
\hline & 2.03 & More than 60 to $70 \mathrm{kgs}$ & & \\
\hline \multirow{3}{*}{ zigzag jogging with ball $30 \mathrm{~m}$} & 8.68 & $50 \mathrm{~kg}$ or less & * & * \\
\hline & 6.32 & More than 50 to $60 \mathrm{kgs}$ & & \\
\hline & 5.93 & More than 60 to $70 \mathrm{kgs}$ & & \\
\hline \multirow{3}{*}{ Running (5om) } & 13.58 & $50 \mathrm{~kg}$ or less & * & * \\
\hline & 11.54 & More than 50 to $60 \mathrm{kgs}$ & & * \\
\hline & $9 \cdot 35$ & More than 60 to $70 \mathrm{kgs}$ & & \\
\hline \multirow{3}{*}{ Flex the trunk forward from long sitting } & 10.15 & $50 \mathrm{~kg}$ or less & * & * \\
\hline & 12.89 & More than 50 to $60 \mathrm{kgs}$ & & * \\
\hline & 14.75 & More than 60 to $70 \mathrm{kgs}$ & & \\
\hline \multirow{3}{*}{ Right-hand grip } & 31.58 & $50 \mathrm{~kg}$ or less & * & * \\
\hline & $39 \cdot 33$ & More than 50 to $60 \mathrm{kgs}$ & & * \\
\hline & 41.96 & More than 60 to $70 \mathrm{kgs}$ & & \\
\hline \multirow{3}{*}{ Left-hand grip } & $24 \cdot 54$ & $50 \mathrm{~kg}$ or less & * & * \\
\hline & 30.00 & More than 50 to $60 \mathrm{kgs}$ & & * \\
\hline & 32.43 & More than 60 to $70 \mathrm{kgs}$ & & \\
\hline
\end{tabular}

\footnotetext{
* It indicates that the means of the two groups differ statistically significant at the 0.05 level
} 
By reviewing the results of the mean differences in the previous table, it is found that they were as follows:

In the zigzag running test for a distance of 30 meters, the differences were between the juniors of the weight category (50 $\mathrm{kg}$ and less) and the category (greater than $50-60 \mathrm{~kg}$ ), so that the significance was in favor of the category (greater than $50-60 \mathrm{~kg}$ ) because the value of their arithmetic mean was the lowest compared to the average of the category ( Also, on the same test, differences appeared between the category (50 kg and less) and the category (greater than $60-70 \mathrm{~kg}$ ), so that the significance was in favor of the category (greater than $50-60 \mathrm{~kg}$ ) because the value of its arithmetic averages was the lowest compared to the average of the category ( $50 \mathrm{~kg}$ or less) and as shown in the previous table

As for the rest of the tests in the table, differences were present between each two age groups, so that the significance is in favor of the age group whose arithmetic average is greater in the jump test from stability, the test for bending the trunk forward from long sitting, and the right and left grip strength test, while the significance is in favor of the lowest arithmetic mean between The two comparative categories in the $50 \mathrm{~m}$ sprint test

\subsection{The fourth research question:}

Are there differences in the levels of physical fitness related to health among junior footballers in AlFaisali Club Academy due to height?

Table 12: Means and standard deviations of physical fitness tests for junior footballers at Al-Faisali Club Academy, distributed according to height $(\mathrm{n}=123)$

\begin{tabular}{|c|c|c|c|c|}
\hline Tests & Height categories & $\mathrm{N}$ & $\mathrm{M}$ & SD \\
\hline \multirow{3}{*}{ Stomach repeat (30 sec) } & Less than $150 \mathrm{~cm}$ & 53 & 21.42 & 2.68 \\
\hline & 150 - less than $160 \mathrm{~cm}$ & 27 & 22.00 & 2.32 \\
\hline & $160 \mathrm{~cm}$ or more & 43 & 22.12 & 2.62 \\
\hline \multirow{3}{*}{ Horizontal jump from stability } & Less than $150 \mathrm{~cm}$ & 53 & 1.60 & 0.25 \\
\hline & 150 - less than $160 \mathrm{~cm}$ & 27 & 1.86 & 0.34 \\
\hline & $160 \mathrm{~cm}$ or more & 43 & 2.09 & 0.26 \\
\hline \multirow[t]{3}{*}{ zigzag jogging with ball $30 \mathrm{~m}$} & Less than $150 \mathrm{~cm}$ & 53 & 8.24 & 1.08 \\
\hline & 150 - less than $160 \mathrm{~cm}$ & 27 & 7.58 & 2.31 \\
\hline & $160 \mathrm{~cm}$ or more & 43 & 5.97 & 0.32 \\
\hline \multirow[t]{3}{*}{ Running (5om) } & Less than $150 \mathrm{~cm}$ & 53 & 13.57 & 1.51 \\
\hline & 150 - less than $160 \mathrm{~cm}$ & 27 & 11.31 & 2.10 \\
\hline & $160 \mathrm{~cm}$ or more & 43 & 9.63 & 0.96 \\
\hline \multirow[t]{3}{*}{ Running (100om) } & Less than $150 \mathrm{~cm}$ & 53 & 5.55 & 0.65 \\
\hline & 150 - less than $160 \mathrm{~cm}$ & 27 & 5.32 & 0.22 \\
\hline & $160 \mathrm{~cm}$ or more & 43 & 5.33 & 0.51 \\
\hline \multirow{3}{*}{ Flex the trunk forward from long sitting } & Less than $150 \mathrm{~cm}$ & 53 & 10.19 & 1.28 \\
\hline & 150 - less than $160 \mathrm{~cm}$ & 27 & 12.20 & 2.93 \\
\hline & $160 \mathrm{~cm}$ or more & 43 & 14.87 & 1.23 \\
\hline \multirow{3}{*}{ Right-hand grip } & Less than $150 \mathrm{~cm}$ & 53 & 31.49 & 5.39 \\
\hline & 150 - less than $160 \mathrm{~cm}$ & 27 & 39.04 & 6.25 \\
\hline & $160 \mathrm{~cm}$ or more & 43 & 41.35 & 3.01 \\
\hline \multirow{3}{*}{ Left-hand grip } & Less than $150 \mathrm{~cm}$ & 53 & 23.30 & 3.70 \\
\hline & 150 - less than $160 \mathrm{~cm}$ & 27 & 31.81 & 4.38 \\
\hline & $160 \mathrm{~cm}$ or more & 43 & 32.23 & 3.50 \\
\hline
\end{tabular}

Table (12) shows the values of the mean scores and standard deviations of the physical fitness tests for junior footballers at Al-Faisali Club Academy, distributed according to the categories of the height variable. By reviewing these values, it is found that they are not equal between the categories of the 
height variable shown in the table in each of the fitness tests. To determine whether the differences in the values of these averages are meaningful or statistically significant at the level of significance $(\alpha$ $\leq 0.05$ ), the one-way analysis of variance (ANOVA) was used, and the table (13) shows that:

Table 13: One-way analysis of variance (ANOVA) of physical fitness tests for junior footballers at AlFaisali Club Academy, distributed by height $(\mathrm{n}=123)$

\begin{tabular}{|c|c|c|c|c|c|c|}
\hline Tests & $\begin{array}{l}\text { Source of } \\
\text { variation }\end{array}$ & $\begin{array}{l}\text { Sum of } \\
\text { squares }\end{array}$ & Df & $\begin{array}{l}\text { Sum of } \\
\text { squares }\end{array}$ & $\mathrm{F}$ & Sig \\
\hline \multirow{3}{*}{ Stomach repeat (3o sec) } & Between groups & 13.218 & 2 & 6.609 & \multirow{3}{*}{.990} & \multirow{3}{*}{$\cdot 375$} \\
\hline & Within groups & 801.287 & 120 & 6.677 & & \\
\hline & Total & 814.504 & 122 & & & \\
\hline \multirow{3}{*}{ Horizontal jump from stability } & Between groups & 5.767 & 2 & 2.883 & \multirow{3}{*}{38.474} & \multirow{3}{*}{.000} \\
\hline & Within groups & 8.993 & 120 & .075 & & \\
\hline & Total & 14.760 & 122 & & & \\
\hline \multirow{3}{*}{ zigzag jogging with ball zom } & Between groups & 124.632 & 2 & 62.316 & \multirow{3}{*}{36.758} & \multirow{3}{*}{.000} \\
\hline & Within groups & 203.434 & 120 & 1.695 & & \\
\hline & Total & 328.066 & 122 & & & \\
\hline \multirow{3}{*}{ Running (5om) } & Between groups & $374 \cdot 588$ & 2 & 187.294 & \multirow{3}{*}{82.468} & \multirow{3}{*}{.000} \\
\hline & Within groups & 272.534 & 120 & 2.271 & & \\
\hline & Total & 647.122 & 122 & & & \\
\hline \multirow{3}{*}{ Running (100om) } & Between groups & 1.538 & 2 & .769 & \multirow{3}{*}{2.740} & \multirow{3}{*}{.069} \\
\hline & Within groups & 33.681 & 120 & .281 & & \\
\hline & Total & 35.219 & 122 & & & \\
\hline \multirow{3}{*}{$\begin{array}{l}\text { Flex the trunk forward from } \\
\text { long sitting }\end{array}$} & Between groups & 520.026 & 2 & 260.013 & \multirow{3}{*}{83.913} & \multirow{3}{*}{.000} \\
\hline & Within groups & 371.833 & 120 & 3.099 & & \\
\hline & Total & 891.859 & 122 & & & \\
\hline \multirow{3}{*}{ Right-hand grip } & Between groups & 2513.699 & 2 & 1256.850 & \multirow{3}{*}{51.865} & \multirow{3}{*}{.000} \\
\hline & Within groups & 2907.976 & 120 & 24.233 & & \\
\hline & Total & 5421.675 & 122 & & & \\
\hline \multirow{3}{*}{ Left-hand grip } & Between groups & 2322.545 & 2 & 1161.273 & \multirow{3}{*}{80.882} & \multirow{3}{*}{.000} \\
\hline & Within groups & 1722.918 & 120 & $14 \cdot 358$ & & \\
\hline & Total & 4045.463 & 122 & & & \\
\hline
\end{tabular}

Table (13) shows a one-way analysis of variance for physical fitness tests for junior footballers at AlFaisali Club Academy, distributed according to the height variable. By reviewing the values of the significance level shown in the last column of the table and comparing these values with the value (o.05), it turns out that there are two tests: the repetition of the stomach 30 seconds and the 10oometer running test. The value of the significance level of each of them, respectively (0.375) and (o.069) is greater than 0.05, which means that the means of these two tests do not differ according to the height category of football juniors at Al-Faisali Club Academy. As for the rest of the significance level values, they were less than 0.05 , which indicates and suggests differences between the averages of the other six tests according to the categories of the variable length.

To determine the length categories whose averages differ in each of the six tests (other than the 30-second stomach repetition test and the 1000-meter running test), the Least Significant Difference (LSD) test was used. The following table shows the results of this test (Table 14). 
Table 14: Results of the least significant difference (LSD) test to determine the height categories whose averages differ in fitness tests (statistically significant) for junior footballers at Al-Faisali Club Academy $(\mathrm{n}=123)$

\begin{tabular}{|c|c|c|c|c|}
\hline Tests & $\mathrm{M}$ & Height category & 150 - less than $160 \mathrm{~cm}$ & $160 \mathrm{~cm}$ or more \\
\hline \multirow{3}{*}{ Horizontal jump from stability } & 1.60 & Less than $150 \mathrm{~cm}$ & * & * \\
\hline & 1.86 & 150 - less than $160 \mathrm{~cm}$ & & * \\
\hline & 2.09 & $160 \mathrm{~cm}$ or more & & \\
\hline \multirow{3}{*}{ zigzag jogging with ball zom } & 8.24 & Less than $150 \mathrm{~cm}$ & * & * \\
\hline & $7 \cdot 58$ & 150 - less than $160 \mathrm{~cm}$ & & * \\
\hline & 5.97 & $160 \mathrm{~cm}$ or more & & \\
\hline \multirow{3}{*}{ Running (50m) } & 13.57 & Less than $150 \mathrm{~cm}$ & * & * \\
\hline & 11.31 & 150 - less than $160 \mathrm{~cm}$ & & * \\
\hline & 9.63 & $160 \mathrm{~cm}$ or more & & \\
\hline \multirow{3}{*}{ Flex the trunk forward from long sitting } & 10.19 & Less than $150 \mathrm{~cm}$ & * & * \\
\hline & 12.20 & 150 - less than $160 \mathrm{~cm}$ & & * \\
\hline & 14.87 & $160 \mathrm{~cm}$ or more & & \\
\hline \multirow{3}{*}{ Right-hand grip } & 31.49 & Less than $150 \mathrm{~cm}$ & * & * \\
\hline & 39.04 & 150 - less than $160 \mathrm{~cm}$ & & * \\
\hline & 41.35 & $160 \mathrm{~cm}$ or more & & \\
\hline \multirow{3}{*}{ Left-hand grip } & 23.30 & Less than $150 \mathrm{~cm}$ & * & * \\
\hline & 31.81 & 150 - less than $160 \mathrm{~cm}$ & & \\
\hline & 32.23 & $160 \mathrm{~cm}$ or more & & \\
\hline
\end{tabular}

* It indicates that the means of the two groups differ statistically significant at the 0.05 level

By reviewing the results of the average differences in the table, it is found that they were as follows: In the left fist strength test, the differences between the juniors of the height category (less than 150 $\mathrm{cm}$ ) and the category ( 150 - less than $160 \mathrm{~cm}$ ), so that the significance was in favor of the category (150 - less than $160 \mathrm{~cm}$ ) because the value of their mean score was greater compared to the mean of the category (less than $160 \mathrm{~cm}$ ). Also, in the same test, differences appeared between the category (less than $150 \mathrm{~cm}$ ) and the category $(160 \mathrm{~cm}$ and longer), so that the significance was in favor of the category (16o cm and longer) because the value of its arithmetic mean was greater compared to the average of the category (less than $150 \mathrm{~cm}$ ). As shown in table (14)

As for the rest of the tests in the table, there were differences between each of the two length categories, so that the significance is in favor of the length category whose arithmetic average is the largest in the jump test from stability, the test of bending the trunk forward from long sitting, and the right and left grip strength tests, while the significance is in favor of the lowest arithmetic mean between The two comparative categories in the zom zigzag running test and the 5om sprint test.

\section{Discussion}

4.1 Discussing the results related to the first study question, which states: What are the levels of some health-related physical fitness elements among junior footballers at Al-Faisali Club Academy?

The results in the tables ( 4 and 5 ) indicated that the test results give an indicator close to the normal distribution of the data of the tests of some elements of physical fitness among the players in the study sample and that the decimal percentile scores and the corresponding scores in the tests, and from here it can be said that construction has been reached Standard levels for assessing the level of health-related physical fitness elements for Al-Faisali Football Club Academy players and that these standard levels can be used to evaluate players of similar age, gender, height and weight. They are similar in ability, gender and age, and then these characteristics or results are analyzed statistically to reach standard levels based on logical scientific analysis. 
The researcher believes that these standard levels are necessary to discover talented players who have a future through the adoption of these standard levels of judgment and prediction of the future of the emerging player in football, and this is consistent with what was indicated by the study of Abu Shehab (2001), and the study of Ahmed Hazem (2017), the study of Basem (2008), and a study of Lehan Hard (1992), which aimed to build and define standard levels for some elements of physical fitness by conducting evaluation, diagnosis, evaluation, analysis, classification and other measurement and evaluation tools.

4.2 Discussing the results related to the second study question, which states: Are there differences in the levels of physical fitness among junior footballers in the Al-Faisali Club Academy due to the chronological age?

The results in the tables $(6,7$, and 8$)$ indicated that there are statistically significant differences at the level of significance $(\alpha \leq 0.05)$ in the level of physical fitness elements for Al-Faisali Football Club Academy players, they are attributed to the chronological age variable, as table (6) shows that there are differences in the values of the mean scores and standard deviations of the fitness tests of the junior soccer player, table (8) shows that there are differences between juniors, between every two age groups, and in favor of the older group. It was shown in Table (7) that the running test (10oom) to measure the component of respiratory periodic endurance that there are no differences according to the chronological age of the player. It is at one level, and at this stage, the person enjoys movement, activity and the ability to withstand fatigue, and this was demonstrated by the results of this study.

The researcher believes that the existence of differences in favor of the older age group is a logical thing. The difference in standard levels in favor of the older players due to the growth of physical and mental abilities and the factor of experience and practice also has a role in creating these differences, and this was confirmed by the study of Al-Hadabi (2001) and the study of Abdul Rahman (2012) that there is a development and superiority in the level of physical fitness during the upper age stage.

The researcher also believes that the process of biological development in building body tissues and various functional devices grow and develop from year to year and this affects the levels and physical abilities of the players and physical measurements, and the duration of training is greater than the younger age group and this confirms that the levels of physical fitness are different and in favor of the older age group.

4.3 Discussing the results related to the third study question, which states: Are there differences in the levels of physical fitness among junior footballers in the Al-Faisali Club Academy due to weight?

The results shown in the tables $(9,10$, and 11) showed that there are differences between the young players due to the weight of the player, as the significance was for the largest weight for six tests, except for the stomach test for 30 seconds and the 10oom running test to measure the endurance component. There were no statistically significant differences for these two tests. The researcher referred this result to the fact that football players focus on the element of endurance and muscular strength, so there is a common denominator which is the absence of differences between the players in the element of endurance and strength of the stomach muscles. For the weight variable, these results are in agreement with the results of the study of Bishr (2012) and the study of David (2003), which showed that there are no differences between students for some tests except for the flexibility test.

The researcher also believes that weight affects physical fitness tests, specifically in the component of agility, kinetic and transitional speed, as well as grip strength, and this was confirmed by Milo Slov (2001) that the correlation of physical measurements has an effective and effective relationship in physical and skill performance to raise the level of players and reach them to the best results. 
4.4 Discussing the results related to the fourth study question, which states: Are there differences in the levels of physical fitness among junior footballers in Al-Faisali Club Academy due to height?

The results shown in the tables $(12,13$, and 14) showed that in the repeated tests of the strength of the stomach muscles and running for a distance of $1000 \mathrm{~m}$, there were no individual differences between the players due to the height variable, while there were differences between the averages of the six tests according to the height variable and in favor of the tallest category and through these results it turns out that the variable of length affects positively for the six tests (explosive force, agility, transitional speed, and grip strength for the right and left hand). This same result was when studying the weight variable. The researcher attributes this result to the fact that the biological characteristics and physical growth characteristics of the players affect the result of the physical tests, and this result is consistent with the results of the study Al-Hadabi (2001) and the study of Al-Haliq and Ali (2011), which showed that there are differences between the results of the physical tests attributed to the study variables

\section{Conclusions}

In light of the study results and their discussion, the researcher concludes the following:

- Standard levels were built to assess some elements of fitness related to health among junior footballers.

- There are differences in all the tests due to the study variables except for the 1ooom running test and the 30-second stomach repeat test.

\section{Recommendations}

In light of the study objectives and results, the researcher recommends the following:

1. Adoption of the standard levels that have been built as a basis for determining the level of fitness for young footballers.

2. Building standard levels to measure the physical fitness elements of other games, specifically for juniors.

3. Focusing on the standard levels to guide young people to the sport of the future in which they will be creative.

\section{References}

Abdul Muti, K. A. (2009). Building a Scale of Attitude towards Swimming and its Relationship to Physical and Skill Abilities among Students Applicants to Join the Department of Physical Education, Third International Scientific Conference, Volume 1 - College of Physical Education for Boys - Razqaziq University.

Abu Hatab, F., Al-Sayed, A. O. (1996). Psychological Evaluation, Anglo-Egyptian Library, 2nd Edition, Cairo.

Abu Shehab, IN. Building Standard Levels for Personal Fitness Elements for Goalkeepers in Jordanian Schools, Master Thesis, College of Physical Education, University of Jordan. 2002.

Al-Awadi M, Al-Karawi, (2017). SR Al-Qadisiyah Journal of Physical Education Sciences, Volume 17, Issue 2, December 2017.

Al-Hadabi, B. B. (2001). Building Standard Levels for Some Elements of Physical Fitness for Female Students of Sultan Qaboos University, Master's Thesis, College of Physical Education, University of Jordan, Amman, Jordan.

Al-Hajj, K. (2017). Basics of Sports Training, 1st Edition, Al-Janadriyah for Publishing and Distribution, Amman Jordan.

Al-Haliq, M., Ali, A. Z. (2021). Building Standard Levels for Some Elements of Physical Fitness for Bachelor Students in the College of Physical Education and Sports Sciences, The Hashemite University, Educational Sciences Studies Volume, University of Jordan; 2001, 38 (2), 66-81.

Al-Rahahlah, W. (2006). Building Standard Levels for Physical Fitness Elements for Female Students of the College of Physical Education, University of Jordan, Mutah Journal for Research and Studies, Humanities and Social Sciences Series; 2006, 21 (2), 33-49. 
Bassem, J. (2008). Building a Scale of Legal Knowledge of Handball for Students of the College of Physical Education, Al-Rafidain Journal of Sports Sciences; 2008; 4 (48), 81-96.

Bidzan-Bluma, I., Lipowska, M. (2019). Physical Activity and Cognitive Functioning of Children: A Systematic Review. Int J Environ Res Public Health. 2018;15(4):80o. Published 2018 Apr 19. doi:10.339o/ijerph1504080o

Bishr, A. R. (2012). Building a physical fitness test for Palestinian army personnel and building standard levels for the extracted battery vocabulary, an unpublished master's thesis at An-Najah University in Palestine, College of Graduate Studies.

Chen, W., Hammond-Bennett, A., Hypnar, A., Mason, S. (2019). Health-related physical fitness and physical activity in elementary school students. BMC Public Health. 2018;18(1):195. Published 2018 Jan 30. doi:10.1186/s12889-018-5107-4

Dauenhauer, B., Keating, X., Stoepker, P., Knipe, R. (2019). State Physical Education Policy Changes From 2001 to 2016. J Sch Health. 2019;89(6):485-493. doi:10.1111/josh.12757

DeCelles, J., Hershow, R. B., Kaufman, Z. A. (2016). Process Evaluation of a Sport-Based Voluntary Medical Male Circumcision Demand-Creation Intervention in Bulawayo, Zimbabwe. J Acquir Immune Defic Syndr. 2016;72 Suppl 4(Suppl 4):S304-S308. doi:10.1097/QAI.oooooooooooo1172

Elzinga, K. E., Chung, K. C. (2017). Finger Injuries in Football and Rugby. Hand Clin. 2017;33(1):149-160. doi:10.1016/j.hcl.2016.08.007

Foss, K. D. B., Thomas, S., Khoury, J. C., Myer, G. D., Hewett, T. E. (2018). A School-Based Neuromuscular Training Program and Sport-Related Injury Incidence: A Prospective Randomized Controlled Clinical Trial. J Athl Train. 2018;53(1):20-28. doi:10.4085/1062-6050-173-16

Guillen, M., Pérez-Marín, A. M., Alcañiz, M. (2021). Percentile charts for speeding based on telematics information. Accid Anal Prev. 2021;150:105865. doi:10.1016/j.aap.2020.105865

Miller, J. (2021). Percentile rank pooling: A simple nonparametric method for comparing group reaction time distributions with few trials. Behav Res Methods. 2021;53(2):781-791. doi:10.3758/s13428-020-01466-5

Otani, T. (2017). Yakugaku Zasshi. 2017;137(6):653-658. doi:10.1248/yakushi.16-oo224-1

Paul, D. J., Nassis, G. P. (2015). Testing strength and power in soccer players: the application of conventional and traditional methods of assessment.J Strength Cond Res. 2015;29(6):1748-1758. doi:10.1519/JSC.ooooooooooooo807

Pfirrmann, D., Herbst, M., Ingelfinger, P., Simon, P., Tug, S. (2016). Analysis of Injury Incidences in Male Professional Adult and Elite Youth Soccer Players: A Systematic Review. J Athl Train. 2016;51(5):410-424. doi:10.4085/1062-6050-51.6.03

Rodríguez-Rosell, D., Mora-Custodio, R., Franco-Márquez, F., Yáñez-García, J. M., González-Badillo, J. J. (2017). Traditional vs. Sport-Specific Vertical Jump Tests: Reliability, Validity, and Relationship With the Legs Strength and Sprint Performance in Adult and Teen Soccer and Basketball Players.J Strength Cond Res. 2017;31(1):196-206. doi:10.1519/JSC.oooooooooooo1476

Seiler, S. (2010). What is best practice for training intensity and duration distribution in endurance athletes?. Int $J$ Sports Physiol Perform. 2010;5(3):276-291. doi:10.1123/ijspp.5·3.276

Snedden, T. R., Scerpella, J., Kliethermes, S. A., (2019). Sport and Physical Activity Level Impacts Health-Related Quality of Life Among Collegiate Students. Am J Health Promot. 2019;33(5):675-682. doi:10.1177/o890117118817715

Stricker, P. R., Faigenbaum, A. D., McCambridge, T. M. (2020). Council on Sports Medicine and Fitness. Resistance Training for Children and Adolescents. Pediatrics. 2020;145(6):e20201011. doi:10.1542/peds.2020-1011

Wu, L., Ma, X., Shi, Y. (2015). China National Assessment of Education Quality - Physical Education \& Health (CNAEQ-PEH) 2015: An Introduction. Res Q Exerc Sport. 2019;90(2):105-112. doi:10.1080/02701367.2019.1603762 